\title{
Decreased Fasting Free Fatty Acids with L-Carnitine in Children with Carnitine Deficiency ${ }^{1}$
}

\author{
W. FREDERICK SCHWENK, DANIEL E. HALE, AND MOREY W. HAYMOND \\ Department of Pediatrics, Mayo Clinic and Foundation, Rochester, Minnesota [W.F.S., M.W.H.] and \\ Department of Pediatrics, University of Pennsylvania, Philadelphia, Pennsylvania [D.E.H.]
}

\begin{abstract}
At the time of acute presentation, children with carnitine deficiency may have increased free fatty acid concentrations and hypoglycemia. However, whether carnitine replacement affects the plasma concentration of these substrates remains to be determined. Therefore, to evaluate the effect of carnitine replacement on plasma substrate and hormone concentrations, five children with carnitine deficiency (two idiopathic, two secondary to longchain acyl coenzyme A dehydrogenase deficiency, one secondary to isovaleric acidemia) were fasted overnight before and after treatment with oral carnitine $\left(80 \pm 7 \mathrm{mg} \cdot \mathrm{kg}^{-1}\right.$. $\left.\mathrm{day}^{-1}\right)$. During carnitine supplementation, plasma total carnitine $(19 \pm 4$ versus $45 \pm 6 \mathrm{nmol} / \mathrm{ml}$, pretreatment versus treatment, respectively) and free carnitine $(11 \pm 3$ versus $31 \pm 6 \mathrm{nmol} / \mathrm{ml}$ ), as well as red blood cell total carnitine $(0.057 \pm 0.019$ versus $0.130 \pm 0.019 \mathrm{nmol} / \mathrm{mg}$ of hemoglobin) increased $(p<0.05)$. Fasting plasma glucose $(83 \pm 4$ versus $85 \pm 3 \mathrm{mg} / \mathrm{dl})$ and ketone body $(0.54 \pm 0.18$ and $0.56 \pm 0.20 \mathrm{mM}$ ) concentrations did not change with carnitine supplementation, but plasma free fatty acids $(1.28$ \pm 0.32 versus $0.77 \pm 0.07 \mathrm{mM})$ decreased $(p<0.05)$. No differences in fasting insulin, growth hormone, or cortisol concentrations were observed. Urinary excretion of free carnitine $(0.1 \pm 0.0$ versus $2.4 \pm 0.7 \mu \mathrm{mol} / \mathrm{mg}$ creatinine), total carnitine $(0.3 \pm 0.1$ versus $3.4 \pm 0.9 \mu \mathrm{mol} / \mathrm{mg}$ creatinine) and acyl carnitine $(0.2 \pm 0.1$ versus $0.9 \pm 0.3 \mu \mathrm{mol} /$ mg creatinine) increased $(p<0.05)$ with carnitine supplementation. The decreased plasma free fatty acid concentrations with carnitine supplementation may be due to more efficient fatty acid oxidation and/or increased urinary excretion of fatty acids as acylcarnitines. (Pediatr Res 23: 491-494, 1988)
\end{abstract}

L-Carnitine is now recognized as an essential cofactor in the transport of long-chain fatty acids across the inner mitochondrial membrane where they can undergo $\beta$-oxidation $(1,2)$. Carnitine deficiency, associated primarily with a number of inborn errors of metabolism, can present with a Reye's-like syndrome and profound hypoglycemia (3).

Whereas oral supplementation with L-carnitine has been reported to be useful in the treatment of both the primary (3-7) and secondary $(7-10)$ forms of carnitine deficiency, it remains

Received January 23, 1987; accepted January 11, 1988

Correspondence and reprint requests, Dr. W. Frederick Schwenk, Endocrine Research Unit, Mayo Clinic and Foundation, 200 First Street S.W., Rochester, MN 55905.

Supported by Kendall McGraw Pharmaceuticals and Public Health Service Grants AM26989, AM01226, and RR585, and the Mayo Foundation. W.F.S. was supported by Public Health Service Grant AM07352.

'Presented in part at the November 1985 meeting of the Midwest Society for Pediatric Research and the May 1986 meeting of the Society for Pediatric Research. to be established whether L-carnitine therapy improves fatty acid utilization in these patients. The present studies were therefore undertaken to determine the effect of $\mathrm{L}$-carnitine supplementation on plasma substrate and hormone concentrations in patients with carnitine deficiency.

\section{METHODS}

Patients. Five subjects (weight $=12.3 \pm 1.0 \mathrm{~kg} ;$ height $=91 \pm$ $6 \mathrm{~cm}$ ) with carnitine deficiency were studied (see Table 1).

Patient 1 presented with hypoglycemia associated with a diarrheal illness at age 9 months. At the time of presentation, her plasma free fatty acid concentrations $(4.3 \mathrm{mM})$ were markedly elevated with only moderate ketosis (total ketone body $=2.8$ $\mathrm{mM})$. Because of her sister's clinical history, described below (patient 2), the diagnosis of carnitine deficiency was considered on the basis of low plasma carnitine concentrations and confirmed by measurement of tissue carnitine concentration (muscle: free $=1.8 \mathrm{nmol} / \mathrm{mg}$ of noncollagen protein, normal $8-35$ total $=30$, normal $=11-39$; liver: free $=0.9$, normal $=3-14$; total $=1.9$, normal $=5-20$ ). The patient presently is growing and developing normally. The diagnosis of long-chain acyl coenzyme A dehydrogenase deficiency was subsequently confirmed on cultured fibroblasts performed by Dr. D. Hale (Philadelphia Children's Hospital, Philadelphia, PA) [long-chain acyl coenzyme A activity $0.09 \mathrm{nmol}$ of ETF reduced $\cdot \mathrm{min}^{-1} \cdot \mathrm{mg}$ of protein $^{-1}$; normal controls $2.15 \pm 0.22$ (mean \pm SD)].

Patient 2 was the older sibling of patient 1 . At age 9 months, she presented with a Reye's-like syndrome that left her with profound psychomotor retardation, spastic quadriplegia, and probable cortical blindness. The diagnosis of carnitine deficiency was not made at the time of her initial illness, but only several years later (see patient 1 above). Several months after completion of this study, she died of aspiration pneumonia. On the basis of low plasma carnitine concentrations and her sister's fibroblast results, she also presumably had a defect in long-chain acyl coenzyme A dehydrogenase.

Patient 3 presented with a Reye's-like illness at age 6 months, which left her with a severe spastic quadriplegia, profound psychomotor retardation, and a severe seizure disorder. The diagnosis of carnitine deficiency was confirmed by muscle and liver biopsy at age 10 months (muscle: free $=8.7 \mathrm{nmol} / \mathrm{mg}$ of noncollagen protein, normal $=8-35$; total $=10.3$, normal $=11-39$; liver: free $=1.6$, normal $3-14$; total $=2.2$, normal $5-20$ ). The etiology of her carnitine deficiency is unknown. Plasma and urinary amino and organic acids were normal as were her longand medium-chain acyl coenzyme A dehydrogenase and isovaleryl coenzyme A dehydrogenase activities determined on fibroblasts.

Patient 4 developed Reye's-like symptoms at age 9 months, 3 days after a motor vehicle accident. His plasma carnitine concentrations were normal at the time of the illness, but were later remeasured over the next 6 months and found to be low. The 
Table 1. Characterization of study group

\begin{tabular}{|c|c|c|c|c|c|c|c|}
\hline \multirow[b]{2}{*}{ Patient } & \multirow{2}{*}{$\begin{array}{l}\text { Age } \\
(\mathrm{mo})\end{array}$} & \multirow{2}{*}{$\begin{array}{c}\text { Reye's-like } \\
\text { presentation }\end{array}$} & \multirow{2}{*}{$\begin{array}{c}\text { Central nervous system } \\
\text { damage }\end{array}$} & \multirow{2}{*}{$\begin{array}{c}\text { Probable } \\
\text { etiology of } \\
\text { carnitine deficiency }\end{array}$} & \multicolumn{3}{|c|}{ Carnitine concentrations } \\
\hline & & & & & Plasma & Liver & Muscle \\
\hline 1 & 22 & + & & $\begin{array}{l}2^{\circ} \text { to long-chain acyl } \\
\text { coenzyme A de- } \\
\text { hydrogenase defi- } \\
\text { ciency }\end{array}$ & $\overline{\text { Low }}$ & Very low & Very low \\
\hline 2 & 73 & + & +++ & $\begin{array}{l}2^{\circ} \text { to long-chain acyl } \\
\text { coenzyme A de- } \\
\text { hydrogenase defi- } \\
\text { ciency }\end{array}$ & Low & & \\
\hline 3 & 15 & + & $++t$ & Unknown & Low & Very low & Low normal \\
\hline 4 & 19 & + & & Unknown & Low & Very low & Low normal \\
\hline \multirow[t]{2}{*}{5} & 38 & + & + & $\begin{array}{l}2^{\circ} \text { to isovaleric aci- } \\
\text { demia }\end{array}$ & Very low & & \\
\hline & $38 \pm 11^{*}$ & & & & & & \\
\hline
\end{tabular}

* Mean \pm SE.

diagnosis was confirmed by liver and muscle biopsy (muscle: free $=7.3 \mathrm{nmol} / \mathrm{mg}$ of noncollagen protein, normal $10-50$; total $=13.8$, normal $12-52$; liver: free $=1.9$, normal $3-14$; total $=$ 2.2 , normal $=5-20)$. He appears to be growing and developing normally. Plasma and urinary amino and organic acids were normal; enzyme analyses of long, medium, and short chain fatty acid dehydrogenase activity were within the normal range.

Patient 5 presented at age 7 wk with pancytopenia and encephalopathy. The diagnosis of isovaleric acidemia was made at that time and the patient started on a protein restricted diet and oral glycine. He did well until age $2 \frac{1}{2}$ yr when he presented with Reye's-like symptoms which left him with a spastic hemiparesis. The diagnosis of secondary carnitine deficiency was made after the initial report of secondary carnitine deficiency associated with isovaleric acidemia (11). Liver and muscle biopsies were not performed in this patient because his primary diagnosis was established.

Study design. After informed consent from a parent of each subject, two 14-h overnight fasts were carried out in the Mayo Clinic Clinical Research Center at St. Marys Hospital, Rochester, MN, before and after supplementation with oral carnitine. Throughout each of the fasts, plasma glucose concentrations were determined to ensure that the subjects did not develop hypoglycemia.

Beginning on day 1, L-carnitine $\mathrm{HCl}$ (Kendall-McGaw, Santa Ana, CA) was administered orally to the subjects each morning. The dose was gradually increased over a 4-day period to a mean daily dose of $80 \pm 7 \mathrm{mg} / \mathrm{kg}$.

On days 0 and 10, after a 14-h overnight fast, venous blood samples were obtained and analyzed for free and total carnitine, red blood cell carnitine, glucose, ketone bodies, free fatty acids, insulin, C-peptide, growth hormone, and cortisol. The plasma was placed in chilled tubes containing sodium fluoride (glucose, ketone bodies, and free fatty acids), EDTA (carnitine), and EDTA-benzamadine (hormones). The blood was spun at $4^{\circ} \mathrm{C}$, and the plasma transferred and stored at $-80^{\circ} \mathrm{C}$ until assayed. An equal volume of normal saline was added to the red blood cells in the EDTA tube, the cells resuspended in the saline, and the tube then respun at $1800 \mathrm{rpm}$ for $15 \mathrm{~min}$. The supernatant as well as "buffy coat" was removed and this process repeated twice. After removal of the third aliquot of saline, the cells were transferred to a plastic test tube and stored at $-20^{\circ} \mathrm{C}$. In addition, a first morning urine sample was obtained by bag collection for free, total, and acyl carnitine and creatinine determinations on days 0 and 10 .

Assays. Plasma, urine, and tissue free and total carnitine determinations were carried out using a sensitive radioisotopeenzymatic assay (12). Urinary acyl carnitine concentrations were calculated as the difference between urinary free and total car- nitine. Red blood cell total carnitine was kindly performed on a red blood cell hemolysate by Dr. P. Borum, University of Florida, Gainesville, FL (13). Plasma glucose was determined by a glucose oxidase method (Yellow Springs Instrument Co., Yellow Springs, $\mathrm{OH})$. Plasma ketone body (14) and free fatty acid (15) concentrations were determined by microfluorometric methods. Urine creatinine was determined in the Mayo Clinic laboratories using a standard colorimetric method. Plasma insulin (16), C-peptide (17), growth hormone (18), and cortisol (19) were determined by radioimmunoassay.

Statistics. All data are expressed as mean \pm SE. Statistics were carried out using a paired Student's $t$ test or a Wilcoxin signed rank test.

\section{RESULTS}

Before initiation of $\mathrm{L}$-carnitine supplementation, mean plasma free and total carnitine concentrations, as well as red blood cell total carnitine concentrations were below the normal range for children more than $2 \mathrm{yr}$ of age (Fig. 1). Ten days after initiation of therapy, plasma free $(11 \pm 3$ versus $31 \pm 6 \mathrm{nmol} / \mathrm{ml}$ before and during carnitine therapy, respectively), total (19 \pm 4 versus $45 \pm 6 \mathrm{nmol} / \mathrm{ml})$ and red blood cell total $(0.057 \pm 0.091$ versus $0.130 \pm 0.019 \mathrm{nmol} / \mathrm{mg}$ of hemoglobin) carnitine concentrations increased $(p<0.05)$. On L-carnitine supplementation, the mean plasma free and total carnitine concentrations were within the normal range for children more than 2 yr of age (Fig. 1), although the plasma free and total carnitine concentrations for the patient with isovaleric acidemia were still slightly less than 2 SD from the mean of the normals. The red blood cell total carnitine concentrations were all within the adult normal range. No adverse side effects of L-carnitine therapy were observed during this period.

Subsequent to completion of the study, subject 2 died (see above). Her liver (free and total; 7.8 and $18.4 \mathrm{nmol} / \mathrm{mg}$ noncollagen protein) and muscle (free and total, 10.3 and $18.4 \mathrm{nmol} /$ mg noncollagen protein) carnitine content were normal in samples obtained shortly after death.

Before initiation of the carnitine therapy, the mean plasma free fatty acid concentration was elevated (Table 2 ; normal $<$ $1.1 \mathrm{mM}$ ), as were the individual plasma free fatty acid concentrations in the patient with known secondary carnitine deficiency (patient $1=1.49 \mathrm{mM}$ : patient $3=2.41 \mathrm{mM}$; patient $4=1.12$ $\mathrm{mM}$ ). The mean plasma total ketone body concentration was normal (Table 2 , normal $=0.5 \pm 0.2 \mathrm{mM}$ ).

L-Carnitine supplementation did not affect fasting plasma glucose or ketone body concentrations (Table 2). However, fasting free fatty acid concentrations decreased $(p<0.05) 30 \pm 11 \%$ ( 2.41 to $0.87,1.12$ to $0.92,0.84$ to $0.74,0.56$ to 0.50 , and 1.49 


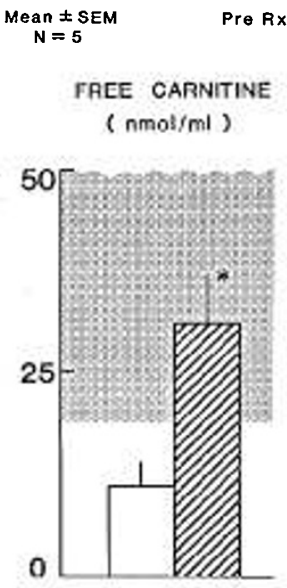

Pre Rx Pormal Range Rx

$* p<0.05$ cf Pre Rx
$+p<0.01$ cf Pre Rx

RBC CARNITINE

( nmolimg $\mathrm{Hg}_{\mathrm{g}}$ )
Mean \pm SEM

$\mathrm{N}=5$

$*_{p}<0.05$ cf Pre Rx
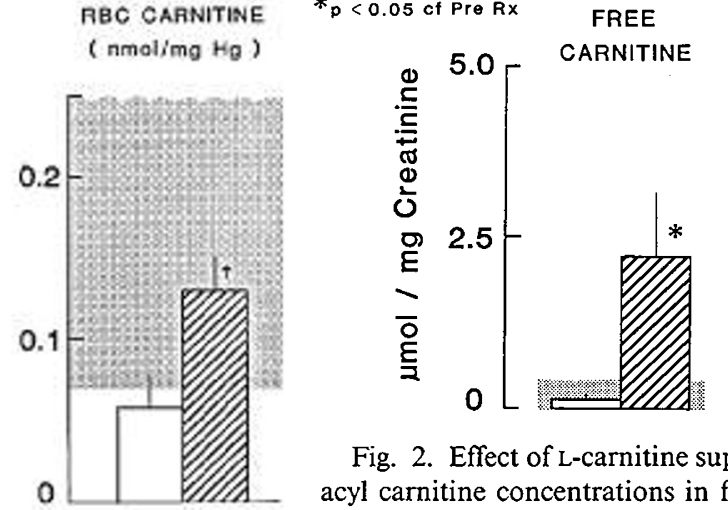

Fig. 1. Effect of L-carnitine supplementation on plasma free and total carnitine and red blood cell total carnitine in five patients with carnitine deficiency. Normal range for plasma free and total carnitine is for children more than $2 \mathrm{yr}$ of age, whereas adult red blood cell total carnitine normal range is depicted.

Table 2. Effect of L-carnitine supplementation on fasting substrate and hormone concentrations (mean $\pm S E$ )

\begin{tabular}{lcc}
\hline & Before carnitine & During carnitine \\
\hline Glucose $(\mathrm{mg} / \mathrm{dl})$ & $83 \pm 4$ & $85 \pm 3$ \\
Ketone bodies $(\mathrm{mM})$ & $0.54 \pm 0.18$ & $0.56 \pm 0.20$ \\
Free fatty acids $(\mathrm{mM})$ & $1.28 \pm 0.32$ & $0.77 \pm 0.07^{*}$ \\
Insulin $(\mu \mathrm{U} / \mathrm{ml})$ & $6.6 \pm 1.4$ & $6.5 \pm 1.1$ \\
C-peptide $(\mathrm{mg} / \mathrm{ml})$ & $0.71 \pm 0.20$ & $0.77 \pm 0.16$ \\
Growth hormone $(\mathrm{ng} / \mathrm{ml}) \dagger$ & $2.2 \pm 0.3$ & $2.9 \pm 0.9$ \\
Cortisol $(\mu \mathrm{g} / \mathrm{dl})$ & $15.3 \pm 1.9$ & $13.4 \pm 2.3$ \\
\hline
\end{tabular}

${ }^{*} p<0.05$ cf before carnitine.

$\dagger n=4$.

to $0.80 \mathrm{mM}$ before and during carnitine for patients $1-5$, respectively; see also Table 2). Fourteen-h fasting plasma free fatty acid concentrations were normal in all five patients. This decrease was not associated with any significant change in the fasting plasma concentrations of insulin, C-peptide, growth hormone, or cortisol (Table 2).

Before initiation of L-carnitine therapy, urinary excretion of L-carnitine, as well as the mean ratio of acyl to free carnitine (subjects $=3.0 \pm 0.7$, normals $=2.0 \pm 1.1$ ), were within normal limits reported for children (Fig. 2) $(20,21)$. Ten days after initiation of treatment, urinary excretion of free, total, and acyl carnitine had all increased $(p<0.05)$ with the mean values well above 2 SD from the mean of normals (Fig. 2), whereas the ratio of urinary acyl to free carnitine had decreased $(p<0.05)$ to 0.31 \pm 0.08 .

\section{DISCUSSION}

L-Carnitine supplementation, in this group of children with carnitine deficiency, normalized plasma free and total carnitine concentrations in four of the five patients and normalized red blood cell total carnitine concentrations in all five. However, normalization of the red cell total carnitine does not guarantee that intrahepatic or intramuscular carnitine concentrations became normal. The normal muscle and liver carnitine concentrations documented in samples taken shortly after death in patient 2 , however, suggest (but do not prove) that the normalization of red blood cell total carnitine may provide an index of intracellular carnitine concentrations in these patients.

This contention is further strengthened by recent studies from our laboratory in which carnitine infusion over a 4-h period failed to alter red blood cell total carnitine content, but red blood
Fig. 2. Effect of L-carnitine supplementation on urine free, total, and acyl carnitine concentrations in five patients with carnitine deficiency. Normal range taken from Reference 20.

cell and liver total carnitine normalized after 30 days of infusion in patients receiving home total parenteral nutrition (22).

L-Carnitine supplementation lowered fasting free fatty acid concentrations, but did not affect those of glucose or ketone bodies. This lowering of fatty acid concentrations by carnitine is similar to that observed in animals $(23,24)$ and patients with diabetes (25), type IV hyperlipoproteinemia (26), and renal disease undergoing dialysis (27). Several explanations for this decrease in plasma free fatty acid concentrations are possible. Inasmuch as ketone body concentrations did not decrease along with free fatty acids, normalization of L-carnitine concentrations may have improved the efficiency of ketogenesis. Increased ketogenesis might not have been expected, however, because two of the subjects had a defect in long-chain acyl coenzyme A dehydrogenase. In addition, increased urinary excretion of free fatty acids as acyl carnitine may have been responsible for some of the decrease in the plasma concentration of the free fatty acids. Because it was not possible to collect accurate 24-h urine samples in these children, and because free fatty acid flux (e.g. palmitate flux) was not measured, it is not possible to estimate the contribution of urinary loss of free fatty acids as acyl carnitines to the decrease in plasma free fatty acid concentrations. The mechanism(s) responsible for this fall in plasma free fatty acids remains to be elucidated.

Whereas our study suggests a positive therapeutic result after carnitine supplementation in children with carnitine deficiency, it should be pointed out that the group of children studied are heterogeneous with respect to the cause of their carnitine deficiency. Therefore, the normalization of blood (and tissue) carnitine values observed herein cannot be extrapolated to all children with carnitine deficiency. In addition, normalization of plasma or tissue carnitine concentrations in children with defects in fatty acid or amino acid metabolism $(11,28,29)$ should not be construed as protecting these children from the development of a recurrence of their Reye's-like symptoms at times of catabolic stress, and may not alter currently recommended supportive therapy now widely recognized (3).

Acknowledgments. The authors thank Joan Aikens for technical assistance and Marylee Campion and Karen Wagner for secretarial help.

\section{REFERENCES}

1. Fritz IB 1968 The metabolic consequences of the effects of carnitine on longchain fatty acid oxidation. In: Gram FC (ed) Cellular Compartmentalization and Control of Fatty Acid Metabolism. Academic Press, New York, pp 3963

2. Rebouche CJ, Engle AG 1983 Carnitine metabolism and deficiency syndromes. Mayo Clin Proc 58:533-540

3. Chapoy PR, Angelini C, Brown WJ, Stiff JE, Shug AL, Cederbaum SD 1980 Systemic carnitine deficiency: a treatable inherited lipid storage disease presenting as Reye's syndrome. N Engl J Med 303:1389-1394 
4. Engel AG, Rebouche CJ 1982 Pathogenic mechanisms in human carnitine deficiency syndromes. In: Schotland DL (ed) Disorders of the Motor Unit. John Wiley and Sons, New. York, pp 643-656

5. Waber LJ, Valle D, Neill C, DiMauro S, Shug AL 1982 Carnitine deficiency presenting as familial cardiomyopathy: a treatable defect in carnitine transport. J Pediatr 101:700-705

6. Tripp ME, Katcher ML, Peters HA, Gilbert EF, Arya S, Hodach RJ, Shug AL 1981 Systemic carnitine deficiency presenting as familial endocardial fibroelastosis: a treatable cardiomyopathy. N Engl J Med 305:385-390

7. Borum PR, Bennett SG, Cheatham JP, Haymond MW, Irias JJ, Merritt RJ Schwenk WF, Wolfsdorf JI, Storm MC 1985 Treatment of genetic carnitine deficiency with oral carnitine supplementation. JPEN 9:119

8. Allen RJ, Wong P, Rothenberg SP, DiMauro S, Headington JT 1980 Progressive neonatal leukoencephalomyopathy due to absent methylene-tetrahydrofolate reductase, responsive to treatment. Ann Neurol 8:211

9. Roe CR, Boham TP 1982 L-Carnitine therapy in proprionicacidemia. Lancet $1: 1411-1412$

10. Ohtani Y, Endo F, Matsuda I 1982 Carnitine deficiency and hyperammonemia associated with valproic acid therapy. J Pediatr 101:782-785

11. Stanley CA, Hale DE, Whiteman DEH, Coates PM, Vudkoff M, Berry GT Segal S 1983 Systemic carnitine (carn) deficiency in isovaleric acidemia (IVA). Pediatr Res 17:296A

12. Engel AG, Rebouche CJ, Wilson DM, Glasgow AW, Romshe CA, Cruse RP 1981 Primary systemic carnitine deficiency. II. Renal handling of carnitine. Neurology (NY) 31:819-825

13. Borum PR, York CM, Bennett SG 1985 Carnitine concentrations of red blood cells. Am J Clin Nutr 41:653-656

14. Miles JM, Nissen SL, Rizza RA, Gerich JE, Haymond MW 1983 Failure of infused $\beta$-hydroxybutyrate to decrease proteolysis in man. Diabetes 32:197205

15. Miles JM, Glasscock R, Aikens J, Gerich J, Haymond M 1984 Amino fluorometric method for the determination of free fatty acids in plasma. J Lipid Res 24:96-99

16. Herbert V, Lau K, Gottlieb CW, Bleicher SJ'1965 Coated charcoal immunoassay of insulin. J Clin Endocrinol Metab 25:1375-1384

17. Faber OK, Binder C, Markussen J, Heding LG, Naithani VK, Kuzuya H, Blix P, Horwitz DL, Rubenstein AH 1978 Characterization of seven C-peptide antisera. Diabetes 27(suppl 1):170-177
18. Peake G 1974 Growth Hormone. In: Jaffe BM, Behrman HR (eds) Methods of Hormone Radioimmunoassay. Academic Press, Inc., New York, pp 103123

19. Beitins IZ, Shaw MH, Kowarski A, Migeon CJ 1970 Comparison of competitive protein binding radioimmunoassay of cortisol to double-isotope dilution and Porter Silber Method. Steroids 15:765-776

20. Chalmers RA, Roe CR, Stacey TE, Hoppel CL 1984 Urinary excretion of Lcarnitine and acyl carnitines by patients with disorders of organic acid metabolism: evidence for secondary insufficiency of $L$-carnitine. Pediatr Res 18:1325-1328

21. Cederblad G, Hermansson G, Ludvigsson J 1982 Plasma and urine carnitine in children with diabetes mellitus. Clin Chim Acta 125:207-217

22. Bowyer BA, Miles JM, Fleming CR, Haymond MW, Borum PR 1986 Effect of intravenous $\mathrm{L}$-carnitine on red blood cell carnitine content in normal humans and patients on home parenteral nutrition. Clin Res 34:793A

23. Abdel Kader MM, Abdel Hay A, Kamel G, Abdel Aziz MT, Fayek KI 1970 Effect of carnitine, $\beta$-methylcholine, and betaine on blood lipid components of the dog. Acta Biol Med Germ 24:1-11

24. Hosein EA, Bexton B 1975 Protective action of carnitine on liver lipid metabolism after ethanol administration to rats. Biochem Pharmacol 24:1859-1863

25. Bekaert J, Deltour $G 1960$ Effet de la carnitine sur l'hyperlipidemie diabetique. Clin Chim Acta 15:177-180

26. Maebashi M, Kawamura N, Sato M, Yoshinaga K, Suzuki M 1978 Lipidlowering effect of carnitine in patients with type IV hyper lipoproteinemia. Lancet 2:805-807

27. Guarnieri GR, Ranieri F, Toigo G, Vasile A, Ciman M, Rizzoli V, Moracchiello $M$, Campanacci L 1980 Lipid-lowering effect of carnitine in chronically uremic patients treated with maintenance hemodialysis. Am J Clin Nutr 33:1489-1492

28. Turnbull DM, Bartlett K, Stevens DL, Alberti KGMM, Gibson GJ, Johnson MA, McCulloch AJ, Sherratt HSA 1984 Short-chain acyl Co-A dehydrogenase deficiency associated with a lipid-storage myopathy and secondary carnitine deficiency. N Engl J Med 311:1232-1236

29. Duran M, Mitchell G, de Klerk JB, de Jager JP, Hofkamp M, Bruinvis L, Ketting D, Saudubray J, Wadman SK 1985 Octanoic acidemia and octanoylcarnitine excretion with dicarboxylic acidemia due to defective oxidation of medium-chain fatty acids. J Pediatr 107:397-404 